\title{
Impact of Marketing Strategy on Business Performance A Study of Selected Small and Medium Enterprises (Smes) In Oluyole Local Government, Ibadan, Nigeria.
}

\author{
Gbolagade Adewale, Adesola M.A, Oyewale I.O \\ Department Of Marketing The Polytechnic, Ibadan Tel: 08033458715 \\ Department Of Business Administration Osun State Polytechnic, Iree \\ Department Of Business Administration Osun State Polytechnic, Iree
}

\begin{abstract}
This research paper investigates the impact of marketing strategy on business performance with special reference to the selected SMEs in Oluyole local government area Ibadan, Nigeria. The survey research design method was used in this study which involves using a self-design questionnaire in collecting data from one hundred and three (103) respondents. The instrument used in this study is a close-ended questionnaire that was designed by the researchers. Correlation coefficient and multiple regression analysis were used to analyze the data with the aid of statistical package for social sciences (SPSS) version 20. The results show that the independent variables (i.e Product, Promotion, Place, Price, Packaging and After sales service) were significant joint predictors of business performance in term of profitability, market share, return on investment, and expansion. $\left(F(6,97)=14.040 ; R^{2}=0.465 ; P<.05\right)$. The independent variables jointly explained $46.5 \%$ of variance in business performance. Subsequently, recommendation were made to SMEs operators to produce quality products; charge competitive prices, position appropriately, use attractive package for the product, engage in after sales service and provide other distinctive functional benefits to consumers.
\end{abstract}

Key words: Marketing strategy, Product, Price, Place, Promotion, Packaging,After sales Service and SMEs.

Submitted date 04June 2013

Accepted Date: 10 June 2013

\section{Introduction}

The current globalization market has made companies to see the internationalization of their activities as a way to remain competitive. Marketing strategy has become important tool globally for any organization to remain in competitive market environment and was stronger. Aremu and Lawal (2012) sees strategy as a pattern ofresource allocation decisions made throughout an organization.This encapsulates both desired goals and beliefs about what areacceptable and most critically unacceptable means for achievingthem. Aremu and Lawal, (2012) say that strategy implies that the analysis of the market and itsenvironment, customer buying behaviour, competitive activitiesand the need and capabilities of marketing intermediaries. Marketing strategy therefore, can be defined as a method by which a firm attempts to reach its target markets. Marketing strategy starts with market research, in which needs and attitudes and competitors' products are assessed and continuesthrough into advertising, promotion, distribution and where applicable, customer servicing, packaging, sales and distribution. Marketing strategy must focus on delivering greater value to customers and the firm at a lower cost (Chiliyaet $a l, 2009)$. Owomoyelaet al, (2013) also see marketing strategy as way of providing a quality product that satisfies customer needs, offering affordable price and engaging in wider distribution and back it up with effective promotion strategy. Marketing strategy is a vital prerequisite of Industry's ability to strengthen its market share and minimize the impact of the competition.

Small and medium enterprises (SMEs) are the engine of economy growth and development globally, Nigeria inclusive. By their very nature, SMEs constitute the most viable and veritable vehicle for self-sustaining industrial development (Oyebamiji, kareem and Ayeni. 2013).SMEs in developing countries, like Nigeria are struggling to survive under intense competitive environments both domestic and international. Oyebamiji, kareem and Ayeni (2013) discover that Small and Medium Enterprises (SMEs) in Nigeria have not performed creditably well and hence have not played the expected vital and vibrant role in the economic growth and development of Nigeria. They note that the situation has been of great concern to the government, citizenry, operators, and practitioners. These challenges could be as a result of perceived ineffective marketing strategy which is having negative effect on the organization's performance, product quality, customer satisfaction and profitability. Small and medium enterprises (SMEs) operators need to provide a quality product with good packaging that satisfies customer needs, offering affordable price and engaging in wider distribution and back it 
up with effective promotion strategy in order to survive the pressure from global market competitive environment.

The main objective of this research work is to examine the impact of marketing strategies on business performance with special reference to the selected small and medium enterprises (SMEs) in Oluyole local government, Ibadan, Nigeria.

\section{Literature Review}

There are numerous definitions of marketing strategy in the literature and such definitions reflect different perspectives ( Liet al, 2000). However, the consensus is that marketing strategy provides the avenue for utilizing the resources of an organization in order to achieve its set goals and objectives. Marketing strategy is define as in a given market area, the proper allocation of resources to support enterprises to win competitive advantage. Goi (2005) define marketing strategy as the set of the marketing tools that firms use to pursue their marketing objectives in the target market; the view which was earlier expressed by (Gronroos, 1999, and Osuagwu, 2006).Therefore, the function of marketing strategy is to determine the nature, strength, direction, and interaction between the marketing mix- elements and the environmental factors in a particular situation. According to (owomoyela, et al, 2013), the aim of the development of an organization's marketing strategy development is to establish, build, defend and maintain its competitive advantage. Managerial judgment is important in coping with environmental ambiguity and uncertainty in strategic marketing.

Lin (1993) as cited in Long-Yi and Ya - Huei,(2012) proposes that marketing strategy can be divided into four ways to research that: (1) Dual-oriented marketing strategy: using rational and emotional product name, easy to remember, and pricing to take into account the cost of service and quality orientation, psychological factors and competitors' prices. (2) Rational marketing strategy: the use of functional demands of a rational position, consider after-sales service, warranties, delivery and installation attached by the product factors. (3) Emotional marketing strategy: the emotional appeal to locate, emphasis on physical product shape, color design, the use of emotional product names, and so on memory, attention to product packaging and labeling. (4) Maintenance marketing strategy: consumers are more concerned about price and quality, it is not suitable to use a lot of marketing techniques, manufacturers can improve product packaging and labeling, give a simple name for remember, consider the quality position and competitor pricing during pricing. Lin (1993) divides marketing strategy into four parts, that is dual-oriented, rational, emotional and low involvement, different product types with different marketing strategy, so the manufacturer's marketing strategy can be divided into five parts which is the choice of target market, product strategy, pricing strategy, channel strategy and marketing strategy. He use a total of 29 questions to measure new product marketing strategy and seven points Likert scale is used to measure. When the industry lack of competition, the business performance would be better even when companies are not entirely market-driven, the performance will have a more excellent performance (Kohliet al., 1993).

Previous studies have established relationships between the marketing strategies and performance ( Owomoyelaet al, 2013; Shoham, 2002; Theodosiou\&Leonidou, 2003). Leonidou, Katsikeas and Samiee (2002) propose a study in which a meta-analysis was also conducted to evaluate the relationships between the marketing strategies and performance.

\subsection{PRODUCT STRATEGY}

Kotler and Armstrong (2006) define a product as anything that can be offered to a market for attention, acquisition, use, or consumption that might satisfy a want or need. They further define a consumer product as the product bought by the final consumer for personal consumption. Consumers buy products frequently, with careful planning, and by comparing brands based on price, quality and style.Borden, (1984) sees a product as about quality, design, features, brand name and sizes. Mohammad et al, (2012) also say that product is the physical appearance of the product, packaging, and labelingInformation, which can also influence whether consumers notice a product in-store, examine it, andpurchase it. past researchers have clearly suggested that product influences have a significant impact on business performance (KazemandHeijden, 2006; Kemppainen, Vepsäläinen, andTinnilä, 2008; Ogunmokun and Esther, 2004; Owomoyelaet al, 2013),

\subsection{PRICING STRATEGY}

kotler (2007) defines price as a cost of producing, delivering and promoting the product charged by the organization. Zeithaml (1988) is of the view that monetary cost is one of the factors that influence consumer"s perception of a product's value. Price can be stated as the actual or rated value of a valuable product which is up for exchange; some define it as amount of money paid for product (Kotleret al, 2005). In the studies of Colpan,( 2006); Dooleet al., (2006) and Owomoyelaet al, (2013) they establish significant relationship between price and business performance. The price you set for your product or service plays a large role in its marketability. 
Pricing for products or services that are more commonly available in the market is more elastic, meaning that unit sales will go up or down more responsively in response to price changes (Jones, 2007).

\subsection{PROMOTION STRATEGY}

Zeithamlet al. (1995) describe promotion as part of specific effort to encourage customers to tell others about their services. According to Duncan (2005), promotion is the key to the marketexchange process that communicates with present and potential stakeholders, and the generalpublic. Every firm or store must cast itself into the role of communicator and promoter. Hakansson (2005) also reports that promotion appears as an issue of how to create an optimal mix of marketing communication tools in order to get a product's message and brand from the producer to theconsumer. Borden, (1984) defines promotion as sales promotion, advertising, personal selling, public relations and direct marketing. Kotler, (2007) discovers that Promotions have become a critical factor in the product marketing mix which consists of the specific blend of advertising, personal selling, sales promotion, public relations and direct marketing tools that the company uses to pursue its advertising and marketing objective. Previous researches (Amine and Cavusgil, 2001; Francis and Collins-Dodd, 2004) have established significant relationship between promotion and business performance.

\subsection{PLACE STRATEGY}

Jones, (2007) defines place as any way that the customer can obtain a product or receive a service. Bowersox and Closs (1996) give distribution as another name for place. According to them, it is the third element of the marketing mix, and it encompasses all decisions and tools which relate to making products and services available to customers. Kotler and Armstrong (2006),also define place or distribution as a set of interdependent organizations involved in the process of making a product available for use or consumption by consumers. Place strategy calls for effective distribution of products among the marketing channels such as the wholesalers or retailers (Berman, 1996). Owomoyela et al, (2013); Amine and Cavusgil, \{2001\}; and McNaughton,( 2002) agree that place has significant effect on business performance.

\subsection{PACKAGING STRATEGY}

Packaging is a crucial component of the "marketing mix" for a product. It is the "least expensive form of advertising" and is of particular importance at the point of sale, as the package is the manufacturer's last chance to convince the customer to purchase the product (Sajuyigbeet al, 2013). Packaging is a very important marketing strategy to glamorize product in order to attract the consumer's attention. Sometimes packaging is so important that it cost more than the product itself in order to lure the consumers to buy it (Sajuyigbeet $a l$,2013).Olayinka and Aminu (2006) see packaging as all activities of designing and producing the container or wrapper for a product. Kottler (2007) defines packaging as all materials products used for the containment, protection, hard delivery and presentation of goods. Packaging is the protecting products for distribution, storage, sale and use, packaging also refers to the process of design evaluation and production of packages. Packaging can be described as a coordinated system of preparing goods for transport, warehousing information and sell. It is fully integrated into government business, institutional, industry, and personal use (Diana, 2005).Sajuyigbeet al, (2013) point out that packaging is one of the inevitable communication tools that influence buying behavior and enhance business performance.

\subsection{AFTER SALES SERVICE STRATEGY}

After sales service involves a continuous interaction between the service provider and thecustomer throughout the post-purchase product life cycle. At the time the product issold to the customer, this interaction is formalized by a mutually agreed warranty orservice contract. Urbaniak, (2001) defines after sales service as those activities that enhance or facilitate the role and use of the product. (Asugman, et al., 1997) also define after sales service as those activities in which a firm engages after purchase of its product that minimize potential problems related to product use, and maximize the value of the consumption experience. Past researchers (Ruben, 2012; Saccani, et al., 2007;; Raddats, 2011; Goffin and New, 2001) agree that after sales service is a marketing strategy that enhance and establish strong and long relationship with customers, which in long run lead to customer satisfaction, retention and profitability.

\subsection{CHARACTERISTICS OF SMES IN THE NIGERIAN ECONOMY}

In a global context, a general definition of SMEs using size and scale of operation is not easy, but within the fixed co-ordinates of national boundaries, it might be relatively easier. At the 13th Council meeting of the National Council on Industry held in July, 2001 Small and Medium Enterprises (SMEs) were defined by the Council as follows:

\subsubsection{Small-Scale Industry}


An industry with a labour size of 11-100 workers or a total cost of not more thanN50 million, including working capital but excluding cost of land.

\subsubsection{Medium Scale Industry:}

An industry with a labour size of between 101-300 workers or a total cost of over N50 million but not more than N200 million, including working capital but excluding cost of land.

\subsubsection{Large Scale}

An industry with a labour size of over 300 workers or a total cost of over N200 million, including working capital but excluding cost of land.

Aluko, Oguntoye, and Afonja (1975) as cited in Oyebamiji, Kareem and Ayeni (2013) characterised SMEs as follows: 1) The same manager or proprietor finds it difficult to raise short or long term capital from the organized capital market, instead relies on personal savings or loans from friends, relatives or money lenders. 2) The same manager/proprietor handles/supervises the production, financing, marketing and personnel functions of the enterprise. 3) The manager/proprietors vision is confined to the local community in which he carries on his line of business. There is little or no knowledge of the wider or distant markets. 4) The rate of business mortality is high probably because of strong mutual distrust and dominance of the sole proprietor which militates against the formation of partnerships or limited liability companies. 5) The enterprise is generally poorly equipped as the small scale industrialist feels reluctant to accept outside help owing to prejudice or fear that information about the enterprise might reach the tax authorities or a nearby competitor. 6) Little or no account of business costs or revenue is kept and the banking system is hardly utilized. The result is that banking facilities for business financing and expansion are extended to only very few of the industrialists. 7) The level of education of the proprietor is usually very low with a consequent low level of business management technique, skill or market information.

\section{Conceptual Model And Hypotheses}

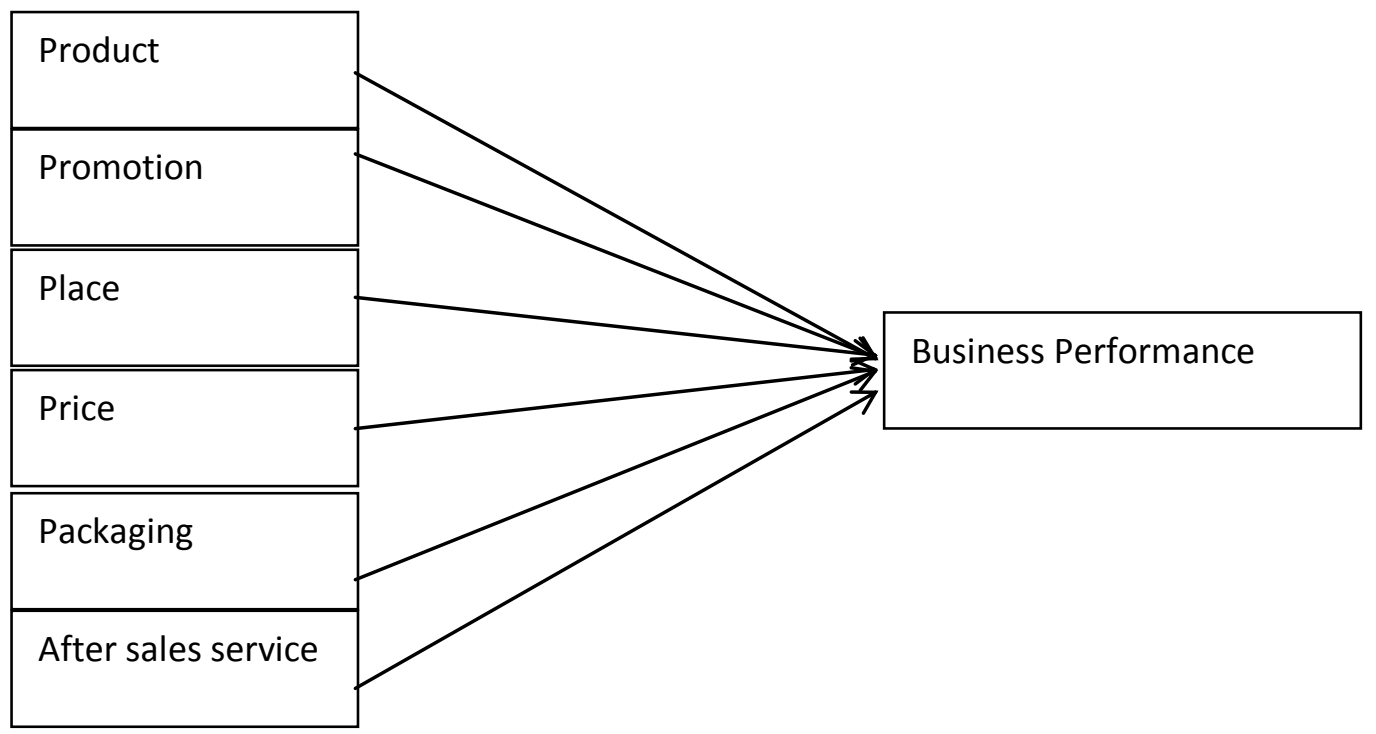

Source: Designed by researchers

The general form of the model was as follows: $\mathrm{BP}=\alpha+\beta 1 \mathrm{X} 1+\beta 2 \mathrm{X} 2+\beta 3 \mathrm{X} 3+\beta 4 \mathrm{X} 4+\beta 5 \mathrm{X} 5+\beta 6 \mathrm{X} 6+\mathrm{e}$ Where, $\mathrm{BP}=$ Business Performance, $\mathrm{X} 1=$ Product, $\mathrm{X} 2=$ Promotion, $\mathrm{X} 3=$ Place $\mathrm{X} 4=$ Price $\mathrm{X} 5=$ Packaging, $\mathrm{X} 6=$ After sales service. And $\alpha$ is constant and $\beta 1, \beta 2, \beta 3, \beta 4, \beta 5$, and $\beta 6$ are coefficient to estimate, and e is the error term.

3.1 RESEARCH QUESTION: Is there significant impact of marketing strategies on business performance?

\section{Hypotheses:}

Hol: Product has no positive significant impact on business performance.

Ho2: Promotion has no positive significant impact on business performance.

Ho3: Place has no positive significant impact on business performance.

Ho4: Price has no positive significant impact on business performance.

Ho5: Packaging has no positive significant impact on business performance. 
Ho6: After sales service has no positive significant impact on business performance.

\subsection{METHODOLOGY}

\subsubsection{Research design and Data collection}

The target population of this study was SMEs operators and their customers in Oluyole local government in Ibadan, Nigeria. The sample for this survey was comprised of one hundred and three (103) respondents who are the SMEs operators and their customers who were randomly selected. A structured questionnaire was used in gathering relevant data from the respondents.

\subsubsection{Measuring instrument}

The measurement used in this paper is the Likert Scale Method of summated ratings. It consists of statements where respondents indicate their degree of agreement or disagreement on a five- point scale Strongly Disagree, Disagree, Neutral, Agree, and Strongly Agree.In respect to measuring the reliability of the scale, the reliability coefficients (Cronbach's _) of the product, promotion, place, price, packaging and after sales service were $0.76,0.85,0.82,0.72,0.80$ and 0.77 respectively. Business performance scale was used to assess respondents' level of their organizational profitability, market share, and return on investment and expansion compare with their competitors. The scale was subjected to item analysis in order to ensure it is valid and reliable and it yielded reliability alpha of .76.

\section{Data Analysis And Interpritation}

Table1: zero - Order Correlation Showing the Relationship between Business Performance and Marketing Strategies.

\begin{tabular}{|c|c|c|c|c|c|c|c|c|c|c|}
\hline & & Mean & SD & 1 & 2 & 3 & 4 & 5 & 6 & 7 \\
\hline & $\begin{array}{l}\text { Business } \\
\text { perform } \\
\text { ance }\end{array}$ & 4.625 & 0.486 & - & $.422 *$ & $-.030 * *$ & $.449 * *$ & $.603 * *$ & $.408^{*}$ & $.434 * *$ \\
\hline 2 & Product & 4.576 & 0.496 & & - & $.087 * *$ & .483 & $.357^{*}$ & $.363^{*}$ & $.399 *$ \\
\hline 3 & $\begin{array}{l}\text { Promoti } \\
\text { on }\end{array}$ & 4.596 & 0.493 & & & - & .087 & .053 & -.127 & .011 \\
\hline 4 & Place & 4.615 & 0.488 & & & & - & .502 & $.035^{*}$ & $.376^{* *}$ \\
\hline 5 & Price & 4.673 & 0.471 & & & & & - & .292 & $.432 *$ \\
\hline & $\begin{array}{l}\text { Packagi } \\
\text { ng }\end{array}$ & 4.615 & 0.488 & & & & & & - & $.292 * *$ \\
\hline 7 & $\begin{array}{l}\text { After } \\
\text { sales } \\
\text { service }\end{array}$ & 4.673 & 0.471 & & & & & & & - \\
\hline
\end{tabular}

Key: $* \mathrm{P}<.05, * * \mathrm{P}<.001$

The result in table 1 shows that the relationship between business performance and product offered to the market, channel of distribution, price charge, packaging of the product and after sales service were positive and significant $(\mathrm{r}=0.422 ; \mathrm{df}=6,97 ; \mathrm{p}<.05 ; \mathrm{r}=0.449, \mathrm{df}=6,97, \mathrm{p}<.01 ; \mathrm{r}=0.603, \mathrm{df}=6,97, \mathrm{p}<.01 ; \mathrm{r}=0.408, \mathrm{df}$ $=6,97, \mathrm{p}<.05$ and $\mathrm{r}=0.434, \mathrm{df}=6,97, \mathrm{p}<.01$ ) respectively. This result implies that the high quality product produced by business organizations, the effective channel of distribution employed by the business organizations, the affordable price charged, the attractive packaging used for the product and the effective after sales serviceengaging in,the higher the business performance, in term of profitability, market share, return on investment, and expansion. However, the relationship between business performance and promotion was negative but significant $(\mathrm{r}=-0.030 ; \mathrm{df}=6,97 ; \mathrm{p}<.01)$. This result is in line with Jayaraman and Wong, (2008) who suggest that it may be due to the consumer perception that heavily promotedproducts could be problematic products of poor quality, with passed expiry dates, and fromclearance stocks. Consumers may also perceive that heavier promotions also mean that theproducts are sold at higher prices, which will turn-off consumers who are in the low-cost segmentof the consumer market.

Table 2

Model Summary ${ }^{\text {b }}$

\begin{tabular}{|l|l|l|l|l|l|}
\hline Model & $\mathrm{R}$ & R Square & $\begin{array}{l}\text { Adjusted } \\
\text { Square }\end{array}$ & $\begin{array}{l}\text { Std. Error of the } \\
\text { Estimate }\end{array}$ & Durbin-Watson \\
\hline 1 & $.682^{\mathrm{a}}$ & .465 & .432 & .36673 & 2.585 \\
\hline
\end{tabular}

a. Predictors: (Constant), After sales service, Promotion, Packaging, Place, Product, Price 
b. Dependent Variable: Business performance

Table 3

ANOVA $^{\mathrm{a}}$

\begin{tabular}{|ll|l|l|l|l|l|}
\hline Model & & Sum of Squares & Df & Mean Square & F & Sig. \\
\hline \multirow{3}{*}{1} & Regression & 11.330 & 6 & 1.888 & 14.040 & $.000^{\mathrm{b}}$ \\
& Residual & 13.045 & 97 & .134 & & \\
& Total & 24.375 & 103 & & & \\
\hline
\end{tabular}

a. Dependent Variable: Business performance

b. Predictors: (Constant), After sales service, Promotion, Packaging, Place, Product, Price

Table 4 Multiple Regression Analysis of Business Performance on Product, Promotion, Place, Price, Packaging and After sales service.

\begin{tabular}{|c|c|c|c|c|c|c|c|c|}
\hline \multirow{2}{*}{\multicolumn{2}{|c|}{ Model }} & \multicolumn{2}{|c|}{ Unstandardized Coefficients } & $\begin{array}{l}\text { Standardized } \\
\text { Coefficients }\end{array}$ & \multirow[t]{2}{*}{$\mathrm{T}$} & \multirow[t]{2}{*}{ Sig. } & \multicolumn{2}{|c|}{$\begin{array}{l}95.0 \% \text { Confidence Interval } \\
\text { for B }\end{array}$} \\
\hline & & B & Std. Error & Beta & & & $\begin{array}{l}\text { Lower } \\
\text { Bound }\end{array}$ & $\begin{array}{l}\text { Upper } \\
\text { Bound }\end{array}$ \\
\hline \multirow{6}{*}{1} & (Constant) & .483 & .609 & & .793 & .430 & -.725 & 1.691 \\
\hline & Product & .129 & .089 & .131 & 1.439 & .003 & -.049 & .306 \\
\hline & Promotion & -.038 & .076 & -.038 & -.499 & .019 & -.188 & .112 \\
\hline & Price & .436 & .094 & .422 & 4.629 & .000 & .249 & .623 \\
\hline & Packaging & .173 & .083 & .174 & 2.085 & .040 & .008 & .338 \\
\hline & $\begin{array}{l}\text { After sales } \\
\text { service }\end{array}$ & .130 & .090 & .126 & 1.442 & .012 & -.049 & .308 \\
\hline
\end{tabular}

a. Dependent Variable: Business performance

Table 2, 3 and 4 show that the independent variables (i.eProduct, Promotion, Place, Price, Packaging and After sales service) were significant joint predictors of business performance in term of profitability, market share, return on investment, expansion and etc. $\left(\mathrm{F}(6,97)=14.040 ; \mathrm{R}^{2}=0.465 ; \mathrm{P}<.05\right)$. The independent variables jointly explained $46.5 \%$ of variance in business performance. Furthermore, product $(\beta=0.131 ; \mathrm{P}<.01)$; place $(\beta$ $=0.062 ; \mathrm{P}<.05)$; price $(\beta=0.422 ; \mathrm{P}<.01)$; packaging $(\beta=0.465 ; \mathrm{P}<.05)$ and after sales service $(\beta=0.126$; $\mathrm{P}<.05)$ were significant independent predictors of business performance. These results are in line with Shaharudinet al, (2009); Muhammed, et al, (2011);Sajuyigbeet al(2013); Francis and Collins-Dodd, (2004); Shamsuddoha and Ali, (2006); Chiliyaet al, (2009)and Owomoyelaet al, (2013) who agreed that marketing mix strategy is the blood of business organization. However, onlypromotion $(\beta=-0.038 ; \mathrm{P}<.05)$ has negative impact but significant on business performance. This result has contrary opinion to the previous researches and this may be due to the consumer perception that heavily promotedproducts could be problematic products of poor quality, with passed expiry dates, and fromclearance stocks. Consumers may also perceive that heavier promotions also mean that theproducts are sold at higher prices, which will turn-off consumers who are in the low-cost segmentof the consumer market.

Table 5: Summary of hypotheses testing

\begin{tabular}{lclll}
\hline Hypothesis & Test & Significant & Result \\
\hline H1. & \multicolumn{2}{c}{ Multiple Regression } & Positive Significant & Rejected \\
H2. & Multiple Regression & Negative Significant & Accepted \\
H3. & Multiple Regression & Positive Significant & Rejected \\
H4. & Multiple Regression & positive Significant & Rejected \\
H5. & Multiple Regression & Positive Significant & Rejected \\
H6. & Multiple Regression & Positive Significant & Rejected \\
\hline
\end{tabular}

\section{Source: Authors' Computation}

\subsection{DISCUSSION}

This study reveals that product consideration has impact on business performance in term of profitability, market share, return on investment, expansion etc. This is because customers do really look at product attributes such as quality, features, design and style. 
The relationship between promotion consideration and business performance is significant, but therelationship is negative. This may be due to the consumer perception that heavily promotedproducts could be problematic products - of poor quality, with passed expiry dates, and fromclearance stocks. Consumers may also perceive that heavier promotions also mean that theproducts are sold at higher prices, which will turn-off consumers who are in the low-cost segmentof the consumer market.

Place consideration is seen to be another factor having an impact on business performance. This simply means the location, accessibility and channel of distribution employed by business organization is a major concern.

The study also indicates that price consideration has a significant positive impact on business performance. This is because many Nigerians' consumers are motivated to buy products at lower prices. The customer base in the lowprice segment of the Nigerian consumer market is big. These consumers in the low-cost segmentalways look for products that offer value for money.

The study also reveals that packaging has positive impact on business performance. This is in line with Chaneta,(2012) who says that packaging can increase sales by such promotionally-oriented moves as offering smaller or larger sizes more multipacks, better pictures of the product itself, illustrations of the product in use and more effective use of color.

Positive significant relationship between after sales service and business performance is established. This simply means customers are motivated to buy product that has guaranty contract, installation and effective delivery.

\section{Conclusion And Recommendations}

The study investigates the impact of marketing strategy on business performance with special reference to the selected small and medium enterprises operators in Oluyole local government area, Ibadan, Nigeria. The study found that marketing strategies (product, place, price, packaging, and after sales service) were significantly independent and joint predictors of business performance. The study however, discovered that promotion has no positive significant effect on business performance. The study conforms to the positions of Shaharudinet al, (2009); Muhammed, et al (2011); Sajuyigbeet al (2013); Francis \& Collins-Dodd, (2004); Shamsuddoha and Ali, (2006); Chiliyaet al, (2009) and Owomoyelaet al, (2013) except the result of promotion which has contrary opinion to the previous researches. Therefore SMEs operators should produce quality products; charge competitive prices, position appropriately, use attractive package for the product, engage in after sales service and provide other distinctive functional benefits to consumers.

\section{References}

[1]. Amine, L. S., and Cavusgil, S. T. (2001). Export marketing strategies in the British clothing industry. European Journal of Marketing, 20(7), 21-33.

[2]. Aremu M.A and Lawal A.T, (2012). Exploring marketing strategy as a catalyst for performance in Nigerian telecommunication industry. IJMBS 2 (4), $65-71$.

[3]. Asugman, G., Johnson, J. L., and McCullough, J. (1997). The role of after-sales service ininternational marketing. Journal of International Marketing, 5(4), 11-28.

[4]. Barney, J. B. (1996). Gaining and sustaining competitive advantage. New York: Addison-Wesley.

[5]. Borden, Neil. H. (1984) The concept of marketing mix, Journal of Advertising Research, 1 (9), 2-7.

[6]. Bowersox, D, and Closs, D J. (1996).Logistic Management: An Integrated Supply Chain Process, New York, McGraw-Hill.

[7]. Chiliya .N, Herbst.G, and Roberts- Combard.M (2009). The impact of marketing stratefieson profitability of small grocery shops in South African Townships. African Journal of Business Management 3 (3), 70 - 79.

[8]. Colpan, A. M. (2006). Dynamic effects of product diversity, international scope and Keiretsu membership on the performance of Japan"s textile firms in the 1990s. Asian Business and Management, 5(3), 419-445.

[9]. Doole, I., Grimes, T., and Demack, S. (2006). An exploration of the management practices and processes most closely associated with high levels of export capability in SEMs.

[10]. Marketing Intelligence and Planning, 24(6), 632-647

[11]. Goffin, K., and New, C. (2001).Customer support and new product development.InternationalJournal of Operations \& Production Management, 21(3), 275-301.

[12]. Goi, C. L. (2005). Marketing Mix: A Review of 'P'.Journal of Internet Banking and Commence, 10

[13]. Grönroos, C. (1999). From Marketing Mix to Relationship Marketing: Towards A ParadigmShift in Marketing Management Decision, 32(2), 4-20

[14]. Jayaraman M and Wong C.H (2008). Relationship between marketing mix strategy and consumer motive: An empirical study in major TESCO Stores. UNITARE E- JOURNAL.4 (2), 41 - 56.

[15]. Jones .S (2007), Exploring corporate strategy: text \& cases. 8th edition.

[16]. Kazem, A., and Heijden, B. V. D. (2006). Exporting firms ${ }^{\text {ee }}$ strategic choices: the case of Egyptian SEMs in the food industry.S.A.M. Advanced Management Journal, 71(3), 21-33.

[17]. Kemppainen, K., Vepsäläinen, A. P. J., \&Tinnilä, M. (2008). Mapping the structural properties of production process and product mix. International Journal of Production Economics, 111(2), 713-728.

[18]. Kotler P (2007). Marketing: An introduction, New Jersey: Pearson Education Inc.

[19]. Kotler, P. and Armstrong, G. (2006). Principles of Marketing, New Jersey, Pearson Education Inc., $10^{\text {th }}$ Edition.

[20]. Kotler P., Ang, S. H., Leong, S. M. and Jan, C. T. (2005). Marketing Management, Asia, Prentice-Hall, $9^{\text {th }}$ Edition.

[21]. Li, T., and Calantone, R. J. (1998). The impact of market knowledge competence on new product advantage:Conceptualizationand empirical examination. Journal of Marketing, 62, October, 13-29. 
[22]. Lin, Lin-Hung (1993), "Consumer Product Classification, Innovation Type and New Product Marketing Strategy.” National Cheng Chi University Department of Business Administration of PhD Thesis.

[23]. Long- Yi .L and Ya-Huei.C (2012).The Impact of New Product Marketing Strategy on New Product Performance: The Moderating Effects of Competitive Intensity and Product

[24]. Innovation.International Journal of advanced scientific research and technology. 2(2), $135-149$.

[25]. Mohammad A.H, Wang A and Sunayya B (2012). Investigating on Tourists satisfaction: An empirical study on East Lake. European journal of business and management. Vol.4 No.7

[26]. McNaughton, R. B. (2002). The use of multiple export channels by small knowledge-intensive firms. International Marketing Review, 19(2), 190-203.

[27]. Ogunmokun, G. O., and Esther, L. L. (2004). Product development process and performance of export ventures: a study of exporting companies in the People ${ }^{e e}$ s Republic of China. Journal of Asia Pacific Marketing, 3(2), 84-98.

[28]. Osuagwu, Linus. (2006). Market Orientations in Nigerian Companies, Intelligence and Planning, 24, (6), 67-73.

[29]. OyebamijiF.F, Kareem T.SandAyeni G.O, (2013).Impact of job satisfaction dimensions on job performance in a small and medium enterprise in Ibadan, South Western, Nigeria.Interdisciplinary Journal Of Contemporary Research In Business. 4 (11), 509 - 521.

[30]. Owomoyela S.K, Oyeniyi K.O and Ola O.S, (2013).Investigating the impact of marketing mix elements on consumer loyalty: An empirical study on Nigerian Breweries Plc.Interdisciplinary Journal Of Contemporary Research In Business. 4 (11), 485 -496.

[31]. Ruben J (2012). Managing after sales services: Strategies and inter firm relationships. PhD Thesis of DiphKfmTechnic.,Universitatstuttgat.

[32]. Saccani, N., Johansson, P. and Perona, M. (2007). Configuring the after-sales service supplychain: A multiple case study. International Journal of Production Economics, 110(1- 2), 52-69.

[33]. Sajuyigbe A.S, Ayanleke S.O and Ola O.S (2013).Impact of packaging on organizational sales turnover: a case study of PatterzonZoconist Cussons (pz) Plc, Nigeria.InterdisciplinaryJournal Of Contemporary Research In Business. 4 (11), 497 - 508.

[34]. Shoham, A. (2002). Standardization of international strategy and export performance: a meta-analysis. Journal of Global Marketing, $16(1-2), 97-120$.

[35]. Urbaniak, A. J. (2001). After the sale: What really happen to customer service. AmericanSalesman, 46(2), 14-17.

[36]. Zeithaml, V.A. (1988) Consumer Perceptions of Price, Quality and Value: A Means-end Model and Synthesis of Evidence, Journal of Marketing, Vol 52 (July), pp. 2-22. 